\title{
KAJIAN HADITS JIBRIL DALAM PERPEKTIF PENDIDIKAN (Kajian Materi Pembelajaran dan Metode Pembelajaran)
}

\author{
Syahrizal Afandi \\ Universitas Islam Negeri Sunan Kalijaga Yogyakarta \\ Email: Syahrizalafandi@gmail.com
}

\begin{abstract}
Abstrak: Kajian ini bertujuan membahas Hadits Jibril pada dua komponen pokok yang bersinggungan langsung dengan proses pembelajaran dalam perspektif pendidikan, yaitu materi, dan metode pembelajaran Nabi Saw. Penelitian ini termasuk dalam kategori penelitian kepustakaan (library research). Peneliti mencatat semua temuan secara umum pada setiap pembahasan penelitian yang didapatkan dalam literatur-literatur dan sumber-sumber, mengumpulkan buku/kitab secara bertahap. Data-data tersebut dikumpulkan dengan teknik dokumentasi, yaitu dengan jalan membaca (text reading), kemudian mengkaji, mempelajari, dan mencatat literatur yang ada kaitannya dengan fokus kajian. Hasil Kajian menunjukkan bahwa Materi pendidikan yang terdapat dalam hadits Jibril antara lain: materi keimanan (akidah), materi fiqh (syariat), dan akhlak. Adapun metode pembelajaran dalam hadits Jibril, Nabi saw. menyampaikan materi dalam hadits Jibril dengan metode biwar (dialog, tanya-jawab). Sementara metode hiwar sendiri terdapat beberapa macam, yaitu: hiwar kbithabi atau ta'abudi (percakapan pengabdian), hiwar washfi (percakapan deskriptif), biwar qishashi (percakapan berkisah), biwar jadali (percakapan untuk menetapkan bujjah), biwar nabawi.
\end{abstract}

Kata Kunci: Materi pembelajaran, metode pembelajaran, hadits Jibril, metode pembelajaran Nabi saw.

Title: Study of the hadith of Gabriel in education perspective (study of learning materials and learning methods)

Author: Syahrizal Afandi

Abstract: This study aims to discuss the Hadith Gabriel in two main components in the learning process, namely learning material, and learning methods of the Prophet Muhammad PBUH. This research is included in the category of library research. The researcher records all the findings in general in each study discussion found in the literature and sources, collecting books in stages. The data is collected by documentation techniques, namely by reading (text reading), then reviewing, studying, and recording literature that is related to the focus of the study. The results of the study showed that the educational material contained in the hadith of Gabriel included: material for the faith (aqidah), fiqh (sharia), and morals. The learning method in the hadith Gabriel, the Prophet PUBH deliver material in the Gabriel hadith with the hiwar method (dialogue, question and answer). While there are several types of hiwar methods, namely: hiwar khithabi or ta'abudi (dedication conversation), hiwar washfi (descriptive conversation), hiwar qishashi (talking conversation), hiwar jadali (conversation to establish bujjab), hiwar nabawi.

Keywords: Learning material, learning methods, Hadith Gabriel, the Prophet's learning methods.

DOI: https://doi.org/10.20414/jpk.v15i1.525 


\section{PENDAHULUAN}

Memahami ajaran agama Islam tidak sebatas membaca al-Qur'an dan terjemahanya. Sebab al-Qur'an memiliki bahasa yang tinggi dan ayat-ayatnya tidak selalu bisa dipahami hanya melalui terjemahan. Salah satu penjelas dari isi Al-Qur'an adalah hadits atau sunah yang berupa semua perkataan, perbuatan yang disandarkan kepada Nabi Muhammad Saw., yang diberi otoritas oleh Tuhan untuk menyampaikan setiap wahyu kepada umat manusia.

Hadits merupakan warisan Rasulullah yang sampai sekarang masih dipegang umatnya. Harus diakui bahwa terdapat perbedaan yang menonjol antara hadits dan Al-Qur'an dari segi redaksi dan cara penyampaian atau penerimaannya. Dari segi redaksi, diyakini bahwa wahyu Al-Qur'an disusun langsung oleh Allah disampaikan melalui malaikat Jibril kepada Nabi Muhammad Saw. yang kemudian disampaikan kepada para sahabat. Redaksi Al-Qur'an bisa dipastikan tidak mengalami perubahan karena sejak zaman Nabi Muhammad Saw. Al-Qur'an sudah ditulis dan dihafal oleh sekian banyak sahabat dan kemudian disampaikan secara mutawatir oleh sejumlah orang yang mustahil mereka sepakat berbohong. Atas dasar ini AlQur'an menjadi qath'i al-wurud.

Berbeda dengan hadits yang pada umumnya disampaikan dengan redaksi sedikit berbeda dengan redaksi yang diucapkan oleh Nabi Saw. Disamping itu, diakui pula oleh ulama hadits bahwa walaupun pada masa sahabat sudah ada yang menulis teks-teks hadits, namun pada umumnya penyampaian atau penerimaan kebanyakan hadits hanya berdasarkan hafalan para sahabat dan tabi'in. ini menjadikan kedudukan hadits dari segi otentisitasnya adalah zhanni al-wurud.

Walau dengan demikian, itu tidak berarti terdapat keraguan terhadap keabsahan hadits kerana sekian banyak faktor baik pada diri Nabi, para sahabat dan periwayatnya yang saling mendukung sehingga terpelihara hadits-hadits Nabi Saw. Hadits merupakan bagian yang tak terpisahkan dari Al-Qur'an sebagai pegangan hidup setiap muslim sebab ia mempunyai kedudukan yang sama dalam mengamalkan ajaran Islam. Tanpa hadits, ajaran Al-Qur'an tidak dapat dilaksanakan.

Selain itu ruang lingkup hadits yang luas meliputi akidah, ibadah, mualamah, akhlak, pendidikan dan lain sebaginya, menjadikan berada dalam posisi setingkat dibawah Al-Qur'an sehingga dapat dijadikan hujjah dan pegangan bagi umat Islam dalam kehidupan sehari-hari.

Sunah memberikan keteladan baik secara baik dan universal dalam pendidikan. Ia juga memberikan sumber berbagai kehidupan manusia yang relevan dalam segala zaman dan tempat. Sunah kaya dengan konsep-konsep ilmu pengetahuan dan pendidikan yang masih belum diungkap oleh umumnya umat Islam. Penyelenggrakan pendidikan Islam lebih banyak didasarkan pada produk ijtihadiyah ketimbang mengikuti pemahaman teks sunah. Namun interprtasinya tetap mengacu kepada makna sunah atau nilai-nilainya yang modernis tidak 
berarti meningggalkannya sama sekali. Hal ini sangat diperlukan sesuai dengan perkembangan zaman sehingga sunah tetap eksis dan fungsional di tengah-tengah masyarakat Islam.

Salah satu hadits pendidikan yang hampir mencakup semua aspek pendidikan menurut penulis adalah hadits kedatangan malaikat Jibril ketika menemui Nabi Muhammad Saw. yang diriwayatkan oleh Umar bin Khatab dan Abu Hurairah, radhiyallabu 'anbuma. Hadits Jibril adalah sebuah hadits yang memuat definisi tentang Islam, Iman, Ihsan, dan tanda-tanda hari kiamat menurut akidah umat Islam, yang terdapat dalam kitab Shahih Muslim no. 8, Shahih Bukhari no. 50, Arbain Nawawi hadits ke-2.

Dari Umar bin Khattab berkata:

"Suatu ketika, kami (para sahabat) duduk di dekat rasululah Saw. Tiba-tiba muncul kepada kami seorang lelaki mengenakan pakaian yang sangat putib dan rambutnya amat bitam. Tak terlibat padanya tanda-tanda bekas perjalanan, dan tak ada seorang pun di antara kami yang mengenalnya. Ia segera duduk di hadapan nabi, lalu lututnya disandarkan kepada lutut nabi dan meletakekan kedua tangannya di atas kedua paba nabi. Kemudian ia berkata: "Hai, Muhammad! Beritahukan kepadaku tentang Islam." Rasulullah Saw. menjawab, 'Islam adalah, engkau bersaksi tidak ada yang berhak diibadabi dengan benar melainkan hanya Allah, dan sesunggubnya Muhammad adalah Rasul Allah; menegakekan shalat; menunaikan zakat; berpuasa di bulan Ramadhan, dan engkau menunaikan haji ke Baitullah, jike engkau telah mampu melakukannya," lelaki itu berkata, "Engkau benar," maka kami heran, ia yang bertanya ia pula yang membenarkannya." Kemudian ia bertanya lagi: "Beritabukan kepadaku tentang Iman". Nabi menjawab, "Iman adalah, engkau beriman kepada Allab; malaikatNya; kitab-kitabNya; para RasulNya; hari Akbir, dan beriman kepada takdir. Allah yang baik dan yang buruk," ia berkata, "Engkau benar." Dia bertanya lagi: “Beritahukan kepadaku tentang ihsan”. Nabi Saw. menjawab,"Hendaklah engkau beribadah kepada Allah seakan-akan engkau melihatNya. Kalaupun engkau tidak melihatNya, sesunggubnya Dia melihatmu." Lelaki itu berkata lagi: "Beritahukan kepadaku kapan terjadi Kiamat?" Nabi menjawab, "Yang ditanya tidaklah lebih tabu daripada yang bertanya." Dia pun bertanya lagi : "Beritabukan kepadaku tentang tanda-tandanya!” Nabi menjawab, "Jika seorang budak wanita telah melabirkan tuannya; jika engkau melihat orang yang bertelanjang kaki, tanpa memakai baju (miskin papa) serta pengembala kambing telah saling berlomba dalam mendirikan bangunan megah yang menjulang tinggi." Kemudian lelaki tersebut segera pergi. Aku pun terdiam, sehingga nabi bertanya kepadaku: "Wahai, Umar! Tahukah engkau, siapa yang bertanya tadi?" Aku menjawab, "Allah dan RasuINya lebih mengetahui," Dia bersabda, "Dia adalab Jibril yang mengajarkan kalian tentang agama kalian." (HR. Muslim no.8)

Hadits ini juga diriwayatkan dari Abu Hurairah yang dikeluarkan oleh Imam Bukhari dalam kitab hadits shahihnya, Dengan redaksi di akhir hadits yang berbunyi:

“...hari Kiamat termasuk dalam lima perkara yang tidak diketahui kecuali oleh Allah.” Kemudian dia pergi, lalu nabi bersabda, "Panggil dia kembali!" Tetapi orang-orang tidak menemukannya. Dia kemudian bersabda, "Dia adalah Jibril, datang kemari untuk mengajari manusia tentang agamanya". Abu Abdullah berkata: Dia menyatakan semua hal tersebut merupakan bagian dari keyakinan." (HR. Al-Bukhari, no. 50)

Menurut penulis hadits tersebut memuat sebuah sistem pendidikan yang jika dapat digambar adalah sebagai berikut: (1) materi pembelajaran (2) metode pembelajaran Rasulullah. Maka dengan demikian tulisan ini akan memaparkan bagaimana hadits Jibril dalam prespektif pendidikan dengan fokus utama pada dua tema besar yakni, pertama, materi pembelajaran dalam Hadits Jibril, kedua, metode pembelajaran Nabi Saw. dalam Hadits Jibril.

\section{METODE KAJIAN}

Penelitian ini termasuk dalam kategori penelitian kepustakaan (library research), yaitu, pertama, dengan mencatat semua temuan mengenai motivasi konsumsi secara umum pada 
setiap pembahasan penelitian yang didapatkan dalam literatur-literatur dan sumber-sumber, dan atau penemuan. dalam penelitian kepustakaan, mengumpulkan buku harus secara bertahap, sebab akan kesulitan apabila tidak demikian. Untuk mendapatkan segala kebutuhan tersebut di atas, bisa dihasilkan melalui perpustakaan, toko buku, maktabah syamilah, pusat penelitian dan jaringan internet atau yang lainnya. Dengan menggunakan data-data dari berbagai sumber baik primer maupun sekunder. Data-data tersebut dikumpulkan dengan teknik dokumentasi, yaitu dengan jalan membaca (text reading), kemudian mengkaji, mempelajari, dan mencatat literatur yang ada kaitannya dengan fokus kajian

\section{HASIL DAN PEMBAHASAN}

\section{Materi Pembelajaran dalam Hadits Jibril}

Dalam dunia pendidikan materi pembelajaran menjadi salah satu unsur penting dalam proses pembelajaran. Materi pembelajaran adalah bahan ilmu pengetahuan yang ditetapkan dalam suatu proses pembelajaran. Materi itu pada umumnya ditetapkan dalam silabus suatu mata pelajaran tertentu atau bidang studi tertentu. Di Indonesia umumnya materi pembelajaran secara garis besar dibagi dua, yaitu materi ilmu agama dan materi ilmu umum. Ada juga sekolah agama dan sekolah umum, guru agama dan guru umum. Pembagian itu tidak menjadi persoalan, keduanya saling bersinergi karena hakikatnya semua ilmu dari Allah diberikan kepada manusia yang sungguh-sungguh mencarinya, tidak ada dikotomi antara keduanya. Menurut Ahmad Tafsir dalam Abdul Majid Khon di Indonesia materi ilmu agama dimaksud Al-Qur'an, hadits, fikih, akhlak, sejarah Islam, dan bahasa arab. ${ }^{1}$

Hadits Nabi Saw. tentunya banyak ditemukan yang menyebutkan materi pembelajaran tersebut sekalipun tidak persisi mengguanakan nama-nama yang ada saat ini. Namun ada isyarat ke nama-nama tersebut misalnya keimanan, keislamana akhlak, dan lain sebagainya sebagaimana di dalam hadits Jibril.

Selanjutnya penulis mencoba mengemukakan materi pembelajaran yang ada di dalam dalam hadits Jibril dan beberapa hadits yang berkaitan dengan materi pembelajaran:

a. Keimanan

Di dalam hadits Jibril memang tidak secara pasti menyebutkan bahwa iman (keimanan) sebagai materi dari sebuah pembelajaran di sebuah lembaga pendidikan. Namun jika kita perhatikan pada saat ini ada materi akidah akhlak yang diajarkan disemua lembaga pendidikan baik pendidikan dasar sampai perguruan tinggi ternyata memuat materi tentang iman.

Iman menurut bahasa berarti kepercayaan, keyakinan, ketetapan hati, atau keteguhan hati. $^{2}$ sedangkan dalam bahasa Arab dengan kata dasar amana-yu'minu-imanan yang artinya

${ }^{1}$ Abdul Majid Khon, Hadist Tarbawi "Hadist-hadist Pendidikan", (Jakarta: Kencana Prenadamedia Grup, 2014), hlm.

2 WJS. Poerdarwinta, Kamus Bahasa Indonesia, (Jakarta: Balai Pustaka, 2000), hlm. 18. 
beriman atau percaya. Percaya dalam bahasa Indonesia artinya menyakini atau yakin bahwa sesuatu (yang dipercaya), memang benar atau nyata. ${ }^{3}$

Sedangkan dalam hadits Jibril pengertian iman adalah:

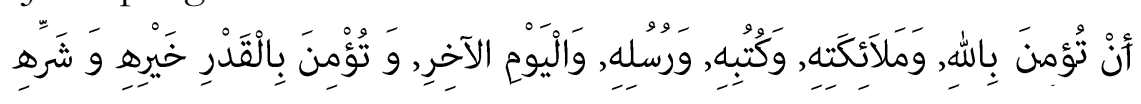

'Iman adalah, engkau beriman kepada Allab; malaikatNya; kitab-kitabNya; para RasulNya; hari Akbir, dan beriman kepada takdir. Allah yang baik dan yang buruk.

Meski esensi iman itu tasdiq sebagaimana tersebut di atas, namun tidak cukup demikian, iman menuntut lebih dari pengucapan lisan namun juga keyakinan dengan hati dan perilaku konkret sebagai realisasi. Sebagaimana hadits Nabi yang diriwayatkan oleh Ibnu Majah ${ }^{4}$

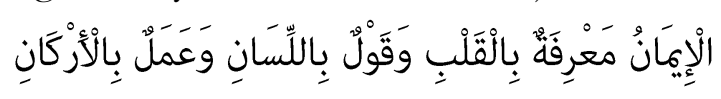

Iman adalah pengakuan dengan hati, pengucapan melalui lidah dan pengamalan dengan anggota badan" (HR. Ibnu Majab: 64)

Maka dengan demikian bisa dikatakan bahwa iman adalah kesatuan tiga dimensi yakni pembenaran, pengucapan dan pengalaman. Ketiga unsur ini harus berjalan serasi dan tidak boleh timpang antara satu sama lainnya. Apa yang dipercaya hendaknya diikrarkan dengan lisan, disesuaikan dengan perbuatan, bukan sebaliknya lain di mulut lain di hati dan lain pula apa yang dilakukannya.

Jika kita perhatikan dari hadits Jibril ada beberapa unsur iman dalam hadits tersebut yakni: (1) Iman kepada Allah (2) Iman kepada malaikat Allah (3) Iman kepada kitab-kitab Allah (4) Iman kepada rasul-rasul Allah (5) Iman kepada hari kiamat (6) Iman kepada takdir baik dan buruk.

Sebagaimana telah disebutkan diatas bahwa hadits Nabi mengenai materi pembelajaran tidak disebutkan secara persis namun ada isyaratkan yang menunjukan kearah tersebut sebagaimana hadits berikut:

Dari Ibnu Abbas r.a berkata "pada suatau hari saya (membonceng) dibelakang Nabi Saw. kemudian beliau bersabda: "wahai pemuda sesunggubnya saya akan mengajarkan beberapa kalimat (hal) kepadamu: peliharalah perintah Allah niscaya kamu akan mendapatkan Allah selalu di hadapanmu. Apabila kamu minta (berdoa), mintalah kepada Allah dan jika kamu minta pertolongan, minta kepada Allah. Ketabuilah olehmu, bahwa seandainya umat manusia berkumpul niscaya mereka tidak dapat memberikan pertolongan kepadamu kecuali sesuatu yang telab ditetapkan oleh Allah atas kamu. Dan seandainya mereka berkumpul untuk mencelakakan kamu sedikitpun juga kecuali sesuatu yang telah ditetapkan oleh Allah atas kamu." Pena telah terangkat dan tulisan-tulisan pada buku catatan telab kering." (HR. Al-Turmudzi dan ia berkata Hadits Hasan Shahih).

Para sarjana pendidikan Islam sepakat bahwa pendidikan keimanan merupakan materi pendidikan vital terhadap anak didik dalam membentuk moral yang baik, sehingga kehidupan anak mempunyai pedoman hidup yang menentramkan dan tidak mudah tergoyah oleh berbagai pengaruh yang disekitarnya. ${ }^{5}$

\footnotetext{
${ }^{3}$ Kaelany HD, Iman, Ilmu dan Amal Saleh, (Jakarta: Rineka Cipta, 2000), hlm. 58.

${ }^{4}$ Ibnu Majah, Sunan Ibnu Majah Juz I Bab Muqadimah, (Semarang: Thaha Putra, tth), hlm. 26.

${ }^{5}$ Abdul Majid Khon, Hadist Tarbawi...hlm. 8.
} 
Jika kita perhatikan hadits di atas ada kalimat "peliharalah perintah Allah niscaya akan memiliharamu" dan juga "jika kamu minta (berdoa), mintalah kepada Allah dan jika kamu minta pertolongan, minta kepada Allah”. Secara tidak langsung kalimat tersebut adalah ungkapan dari Nabi Saw. kepada seorang anak muda yang Ia bonceng untuk memperkuat keimanannya kepada Allah agar tidak terpengaruh oleh lainnya. Sepertinya telah penulis sebutkan diatas bahwa pendidikan iman adalah pendidikan yang vital maka sudah seharusnya lembaga pendidikan menekankan pentingnya pendidikan keimanan kepada peserta didik guna membentuk moral yang baik untuknya dimasa depan.

Dalam pendidikan Islam faktor keimanan sangat penting ditananamkan kepada anak didik, misalnya mengajarkan bahwa Allah Maha Melihat, Maha Mengawasi makhluk-Nya dimana saja berada, tidak ada makhluk apapun yang terlepas dari pengawasan Tuhan dan Allah Maha Penolong dan mencukupi segala yang dibutuhkan manusia dan sebagainya. Demikian juga, seorang dididik menyakini segala yang terjadi baik dan buruk adalah sudah dikehendaki Tuhan.

\section{b. Syariat (Fiqh)}

Ketika malaikat Jibril bertanya kepada Nabi Saw. mengenai Islam yang kemudian dijawab oleh Nabi Saw.:

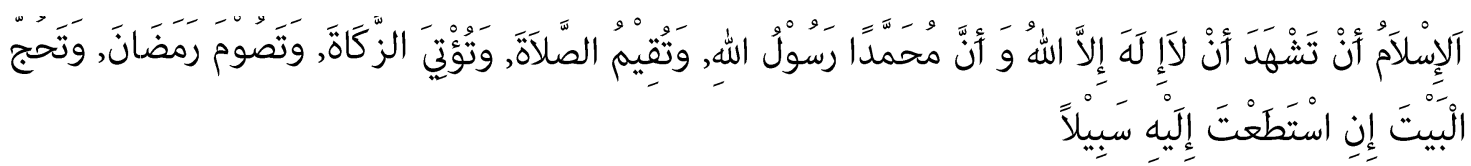

"Islam adalah, engkau bersaksi tidak ada yang berbak diibadabi dengan benar melainkan banya Allah, dan sesunggubnya Mubammad adalah Rasul Allah; menegakean shalat; menunaikan rakat; berpuasa di bulan Ramadhan, dan engkau menunaikan haji ke Baitullah, jika engkau telah mampu melakukannya,"

Didalam hadits lain yang diriwayatkan oleh Bukhari Rasulullah Saw. bersabda:

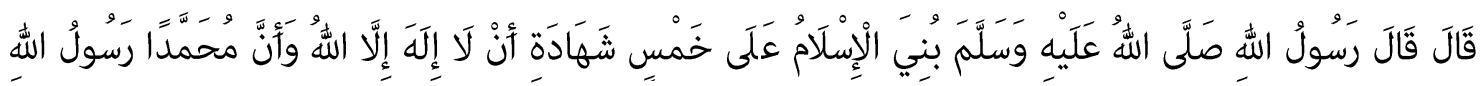

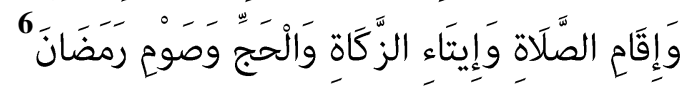

"Islam dibangun atasa lima (landasan) bersaksi tidak Tuban selain Allah dan sesunggubnya Muhammad adadalah utusan Allah, mendirikan shalat, menunaikan zakat, haji dan puasa Ramadhan".

Materi fikih adalah materi agama yang sangat penting bagi anak didik dan menjadi materi yang paling utama. Selain itu materi fikih menjadi salah satu indikator keberhasilan pendidikan agama Islam, jika dikuasai dengan baik berarti pendidikan berhasil, jika tidak dikuasai berarti pendidikan agama tidak berhasil. Penguasaan dan pemahaman di sini dimaksudkan sampai kepada aspek kognitif, psikomotorik, dan afektif. Ayat diatas memberi gambaran bahwa mengingat betapa pentingnya ilmu agama guna memberikan peringatan kepada orang lain maka Allah melarang untuk semua orang pergi berperang.

\footnotetext{
${ }^{6}$ http:/ / hadits.in/bukhari/7
} 
Agama adalah fikih karena mencakup segala perbuatan manusia dalam kehidupannya setelah beriman. Jika dilihat dari urgensi hukum memag sangat urgen, karena agama memang berisikan hukum. Oleh karena itu, orang yang paham hukum adalah orang baik, karena hukum inilah yang mengendalikan aspek terjang dan tingkah laku manusia. Dalam perkembangannya fikih dibagi menjadi empat masalah: fikih ibadah, fikih muamalah (hubungan kerja), fikih munakahat (pernikahan), dan fikih jinayah (kriminal). ${ }^{7}$

\section{c. Akhlak}

Hadits Jibril di atas memang tidak secara persis menggambarkan mengenai materi akhlak, namun disini yang perlu kita garis bawahi adalah ketika Rasulullah Saw. ditanya mengenai pengertian ibsan yang kemudian beliau menjawab

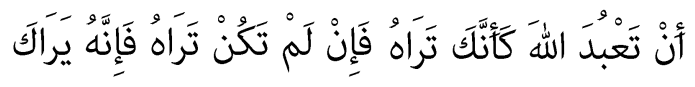

"Hendaklab engkau beribadah kepada Allah seakan-akan engkau melihat Nya. Kalaupun engkau tidak melihatNya, sesunggubnya Dia melibatmu"

Ihsan adalah akhlak sesungguhnya merupakan buah dari ibadah dan muamalah. Seseorang akan mencapai tingkat ihsan dalam akhlaknya apabila ia telah melakukan ibadah seperti yang menjadi harapan Rasulullah Saw. dalam hadits yang yang telah dikemukakan sebagaiman hadits di atas. Jika hal tersebut telah dicapai oleh seorang hamba, maka sesungguhnya itulah puncak ibsan dalam ibadah. Pada akhirnya ia akan berbuah menjadi akhlak atau perilaku, sehingga mereka yang sampai pada tahap ihsan dalam ibdahnya akan terlihat jelas dalam perilaku dan karakternya. ${ }^{8}$

Kaitanya dengan pendidikan adalah bahwa tujuan akhir sebuah pendidikan adalah menjadikan peserta didik seorang yang insan kamil. Selain itu peserta didik yang insan kamil adalah orang mampu bermujahadah (mengendalikan) hawa nafsu untuk taat dan berbuat manfaat untuk dirinya maupun orang lain.

\section{Metode Pembelajaran Rasulullah dalam Hadits Jibril}

Dalam proses belajar mengajar, agar tujuan utama dari pendidikan itu dapat tercapai, guru harus memiliki suatu cara atau metode yang unik, menarik dan menyenangkan dalam menyampaikan pesan kepada peserta didik, dengan model yang unik, menarik dan menyenangkan maka pesan yang diberikan kepada kepada siswa akan mudah diterima dan dicerna oleh siswa. Metode yang digunakan dalam proses pembelajaran sangat berpengaruh terhadap penguasaan siswa kepada pesan yang diberikan, dengan kata lain, dalam proses pembelajaran jika model yang digunakan oleh guru tidak sesuai dengan kondisi maka hasil proses belajar mengajarpun tidak maksimal.

${ }^{7}$ Abdul Majid Khon, Hadist Tarbawi ...hlm. 23.

${ }^{8}$ Ali Imran, Kosep Adil dan Ihsan Menurut Aqidah, Ibadah dan Akblak, Hikmah Vol. VI, No. 02 Juli 2012. 
Salah satu komponen penting untuk mencapai keberhasilan pendidikan dalam mencapai tujuan adalah ketepatan menentukan metode, sebab tidak mungkin materi pendidikan dapat diterima dengan baik kecuali dengan metode yang tepat. Metode diibartkan sebagai alat yang dapat digunakan dalam suatu proses pencapaian tujuan, tanpa metode, suatu materi pelajaran tidak akan dapat berproses secara efesien dan efektif dalam kegiatan belajar mengajar menuju tujuan pendidikan. ${ }^{9}$

Ada beragam metode pembelajaran yang sering digunakan oleh para pendidik dalam kegiatan belajar-mengajar. Diantaranya adalah metode ceramah, metode tanya-jawab, metode diskusi, metode sosio-drama (role playing), metode kerja kelompok, metode pemecahan masalah (problem solving), metode karyawisata (field-trip), metode survai masyarakat, dan sebagainya. ${ }^{10}$

Merujuk pada pola kependidikan dan keguruan Rasulullah Saw. dalam prespektif Islam, guru menjadi posisi kunci dalam membentuk kepribadian muslim sejati. Keberhasilan Rasulullah Saw. dalam mengajar dan mendidik umatnya lebih menyentuh perilaku, yaitu contoh teladan yang baik (uswatun hasanah). Hal ini bukan berarti aspek-aspek selain dari perilaku diabaikan. Aspek perilaku dalam proses pengajaran posisinya sangat penting. Sebagai seorang guru, apalagi seorang guru agama Islam harus menjadi contoh, panutan, idola, dan teladan yang baik (uswatun hasanah) bagi para siswanya. Segala perilaku guru dalam proses pembelajaran, perilaku guru ditiru oleh para siswa. Oleh karena itu guru harus menjaga perilakunya secara baik dan menjadi suri tauladan (uswatun hasanab) bagi siswanya. ${ }^{11}$

Berbicara mengenai metode Rasulullah Saw. dalam mendidikan terdapat dalam sebuah hadits yang diriwayatkan oleh al-Bukhari:

$$
\text { يسروا ولاتعسروا وبشروا ولاتنفروا }
$$

Mudabkanlah dan janganlah kamu mempersulit. Gembirakanlah dan janganlab kamu membuat mereka lari (HR Bukhari).

Dalam hadits diatas, secara tersirat Rasulullah Saw. memerintahkan kepada kita untuk menyelenggarakan suatu kegiatan pembelajaran yang menyenangkan dan tidak sulit. Inilah sebenarnya salah satu metode yang cukup ideal dan bisa memberikan hasil yang optimal.

Dengan berdasarkan hadits Jibril penulis hanya memfokuskan kepada satu metode pembelajaran yang tujuannya adalah agar pembahasan mengenai metode ini tidak menyinggung kepada hadits lain. Metode pembelajaran yang dilakukan Nabi Saw. kepada para sahabat dalam hadits Jibril lebih cenderung kepada metode biwar atau yang dikenal dengan metode dialog.

\footnotetext{
${ }^{9}$ Irjus Indrawan, Model Pembelajaran Nabi Mubammad SAW (Hiwar, Analogi, Tasbih dan Amtsal), Al-Afkar Vol. II No. II, Oktober 2013, hlm. 61.

${ }^{10}$ Gulo, Strategi Belajar Mengajar, (Jakarta: Grasindo, 2002) hlm, 78.

${ }^{11}$ Irjus Indrawan, Model ...hlm. 66.
} 
Adapaun hiwar atau diartikan sebagai dialog antara dua pihak atau lebih yang dilakukan melalui tanya jawab dan di dalamnya terdapat kesatuan topic atau tujuan dialog. ${ }^{12}$ Yang dimaksud biwar adalah percakapan silih berganti antara dua pihak atau lebih melalui tanya jawab mengenai suatu topik yang mengarah pada suatu tujuan. ${ }^{13}$ Percakapan ini bisa dialog langsung dan melibatkan kedua belah pihak secara aktif atau bisa juga yang aktif salah satu pihak saja, sedangkan pihak lain hanya merespon dengan segenar perasaan, pengahayatan dan kepribadiannya. ${ }^{14}$

Mani bin Abd al-Aziz al-Mani dalam H.M Arifin menyebutkan bahwa hiwar disebut juga metode tanya jawab. ${ }^{15}$ Salah satu yang menonjol dari metode Nabi Saw. dalam mengajar adalah kerap kali beliau mengajar para sahabat dengan cara berdialog (biwar) dan tanya jawab. Sebab dialog sangat membantu sekali dalam membuka kebuntuan otak dan kebekuan berfikir. $^{16}$

Perhatikan hadits Jibril berikut:

Dari Umar bin Khattab berkata: "Suatu ketika, kami (para sababat) duduk di dekat rasululab Saw. Tiba-tiba muncul kepada kami seorang lelaki mengenakan pakaian yang sangat putih dan rambutnya amat hitam. Tak terlihat padanya tanda-tanda bekas perjalanan, dan tak ada seorang pun di antara kami yang mengenalnya. I a segera duduk di hadapan nabi, lalu lututnya disandarkan kepada lutut nabi dan meletakekan kedua tangannya di atas kedua paha nabi, Kemudian ia berkata: "Hai, Muhammad! Beritabukan kepadaku tentang Islam." Rasulullah Saw. menjawab, "Islam adalah, engkau bersaksi tidak ada yang berbak diibadabi dengan benar melainkan hanya Allah, dan sesunggubnya Mubammad adalah Rasul Allah; menegakkan shalat; menunaikan zakat; berpuasa di bulan Ramadhan, dan engkau menunaikan baji ke Baitullah, jikea engkau telah mampu melakukannya," lelaki itu berkata, "Engkau benar," maka kami heran, ia yang bertanya ia pula yang membenarkannya." Kemudian ia bertanya lagi: "Beritahukan kepadaku tentang Iman". Nabi menjawab, "Iman adalah, engkau beriman kepada Allah; malaikatNya; kitab-kitabNya; para RasuINya; hari Akbir, dan beriman kepada takdir Allah yang baik dan yang buruk," ia berkata, "Engkau benar." Dia bertanya lagi: "Beritabukan kepadaku tentang ibsan". Nabi Saw. menjawab,"Hendaklah engkau beribadab kepada Allah seakan-akan engkau melibatNya. Kalaupun engkan tidak melihatNya, sesunggubnya Dia melibatmu." Lelaki itu berkata lagi: "Beritahukan kepadaku kapan terjadi Kiamat?" Nabi menjawab, "Yang ditanya tidaklah lebih tahu daripada yang bertanya." Dia pun bertanya lagi: "Beritabukan kepadaku tentang tanda-tandanya!" Nabi menjawab, "Jika seorang budak wanita telah melabirkan tuannya; jika engkau melihat orang yang bertelanjang kaki, tanpa memakai baju (miskin papa) serta pengembala kambing telah saling berlomba dalam mendirikan bangunan megah yang menjulang tinggi." Kemudian lelaki tersebut segera pergi. Aku pun terdiam, sehingga nabi bertanya kepadaku: "Wabai, Umar! Tabukab engkau, siapa yang bertanya tadi?" Aku menjawab, "Allab dan RasuINya lebih mengetabui," Dia bersabda, "Dia adalah Jibril yang mengajarkan kalian tentang agama kalian." (HR. Muslim no.8)

Jika kita perhatikan secara seksama dalam hadits Jibril bagaimana ketika sebenarnya malaikat Jibril yang mengajarkan kepada Nabi Saw. mengenai Iman, Islam dan Ihsan namun dalam penyajiannya semuanya dijelaskan oleh Rasulullah secara sederhana sehingga para

12 Alfiah, Hadist Tarbawiy (Pendidikan Islam dan Tujuan Hadist), (Pekanbaru: Al-Mujtahadah Press, 2010), hlm. 83

13 An-Nahlawi dalam Ahmad Izzan \& Saehuddin, Hadist Pendidikan (Konsep Pendidikan Berbasis Hadist), (Bandung: Humaniora, 2016), hlm. 134.

${ }^{14}$ Irjus Indrawan, Model ...hlm. 68

15 Arifin, Imu Pendidikan Islam, (Jakarta: Bumi Aksara, 1996), hlm. 215.

16 Abudrahma An-Nahlawi dalam Irjus Indrawan, Model ...hlm. 68 
sahabat ketika itu dapat memahaminya dengan jelas, yang kemudian kesemuanya dibenarkan oleh malaikat Jibril.

Metode "biwar" atau dialog mempunyai dampak dan keuntungan yang sangat dalam terhadap jiwa pendengar atau pembaca yang mengikuti topik percakapan secara seksama dan penuh perhatian. Hal ini disebabkan oleh beberapa hal:

1. Permasalah yang disajikan secara dinamis, karena kedua belah pihak langsung terlibat dengan pembicaranya secara timbal balik, sehingga tidak membosankan.

2. Pembaca atau pendengar tertarik untuk terus mengikuti jalannya percakapan itu dengan maksud untuk mengetahui kesimpulannya.

3. Hiwar dapat membangkitkan berbagai perasaaan dan kesan seseorang yaag akan melahirkan dampak pedagogis untuk membantu tumbuhnya ide dalam jiwa serta membantu mengarahkannya pada tujuan akhit pendidikan.

4. Topik disajikan secara realistis dan manusiawi. ${ }^{17}$

5. Mendorong murid lebih aktif dan bersungguh-sungguh.

6. Walaupun agak lambat guru dapat mengontrol pemahaman murid pada masalahmasalah yang dibicarakan.

7. Pertanyaan dapat melatih anak untuk mengingat.

8. Mengembangkan keberanian serta keterampilan siswa dalam menjawab sekaligus mengemukankan pendapat.

9. Timbulnya perbedaan pendapat anak didik akan mengahangatkan proses diskusi.

10. Pertanyaan dapat membangkitkan anak menilai suatu kebenaran. ${ }^{18}$

Ahmad Ihzan dan Saehuddin membagi metode dialog (biwar) dalam beberapa bentuk sebagai berikut: ${ }^{19}$

1. Hiwar khithabi atau ta'abudi (percakapan pengabadian)

Hiwar khitabi atau ta'abudi adalah percakapan antara Allah dengan hamba-Nya dengan menggunakan “nida’ut ta'rif bi al-iman” yaitu dengan serta يايهاالذين امنو setiap kali orang Mukmin membacannya, maka tergugahlah hatinya untuk memjawab: ku sambut panggilan$\mathrm{Mu}$ ya Rabbi. Oleh sebab itu, metode ini disebut dengan metode percakapan. Namun sering terjadi hal sebalinya, yaitu seperti yang terjadi dalam beberapa ayat Al-Qur'an orang mukminlah yang berbicara dengan Rabb-Nya dalam berdoa. Bentuk hiwar khitabi seperti telah dijelaskann dalam sebuah hadits yang diriwayatkan oleh Abu Daud dan Baihaqi, yaitu:

$$
\text { كان رسول الله ص.م: اذا قرا ليس ذلك بقادر على ان يحي الموت؟ قال سبحانك فبلى, واذا قرا سبح اسم ربك }
$$

${ }^{17}$ Ahmad Izzan \& Saehuddin, Hadist Pendidikan,, (Bandung: Humaniora, 2016), hlm. 134.

${ }_{18}$ Bukhari Umar, Hadist Tarbawi (Pendidikan Dalam Prespektif Hadist). (Jakarta: Amzah,2016), hlm. 130.

${ }^{19}$ Ahmad Izzan \& Saehuddin, Hadist Pendidikan,, (Bandung: Humaniora, 2016), hlm. 136-137. 
Apabila Rasulullah Saw. membaca: bukanlah Allah yang membuat demikian berkuasa (pula) menghidupkan orang yang mati? Maka beliau mengucapkan Maha Suci Engkau, yang memamg benar. Dan apabila membaca: Sucikanlah nama Rabb-Mu yang Maha Tinggi maka beliu mengucapkan, Maba Suci Rabb-ku Yang Maha Tinggi (H.R Abu Dawud dan Baihaqi).

Hadits di atas merupakan dalil atas hiwar ta'abudi yang berisikan tetanag penyambutan hamaba terhadap seruan Rabb-Nya atau permohonan hambanya sewaktu membaca alQur'an, seperti tasbih, dan ta'waduz. Hal ini jelas menujukkan hiwar (percakapan).

\section{Hiwar washfi (percakapan deskriptif)}

Hiwar ini merupakan pembicaraan atau dialog antara Allah dengan para malaikat memgenai orang-orang dzalim yang berhak menerima adzab Jahanam. Contohnya di dalam surat As-Shaffat: 20-23.

Didalam sebuah hadits Rasulullah pernah menggambarkan bagaimana keadaan orangorang Arab yang akan celaka karena kedatangan Yajuj dan Majjuj.

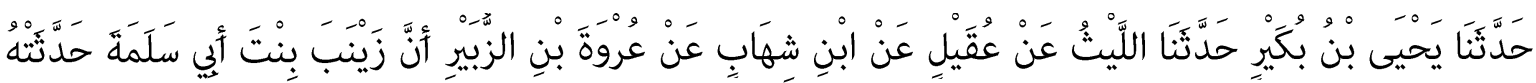

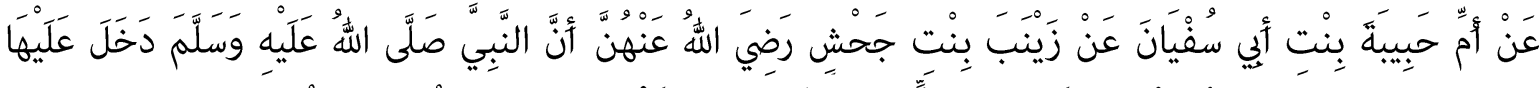

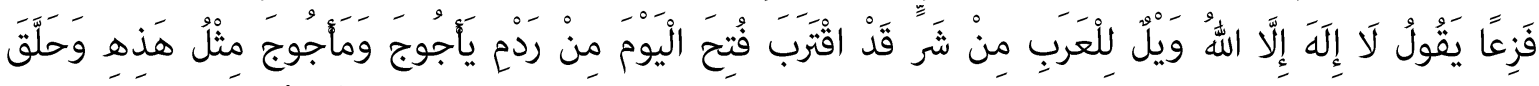

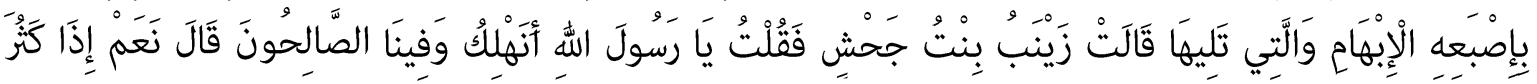

Telah bercerita kepada kami Yahya bin Bukair telah bercerita kepada kami Al Laits dari 'Uqail dari Ibnu Syihab dari 'Urwah bin Az. Zubair bahwa Zainab binti Abu Salamab bercerita kepadanya dari Ummu Habibah binti Abu Sufyan dari Zainab binti Jahsy radliallabu 'anbuma babwa Nabi shallallahu 'alaibi wasallam datang kepadanya dengan gemetar sambil berkata: "Laa ilaaba illallah, celakalah bangsa Arab karena keburukan yang telah dekat, hari ini telah dibuka benteng Yajuj dan Ma'juj seperti ini". Beliau memberi isyarat dengan mendekatkan telunjuknya dengan jari sebelahnya. Zainab binti Jahsy berkata, Aku bertanya; "Wabai Rasulullah, apakah kita akan binasa sedangkan di tengah-tengah kita banyak orang-orang yang shalih?". Beliau menjawab: "Ya, benar jika keburukan telab merajalela". (HR. Bukhari: 3097)

\section{Hiwar qishashi (percakapan berkisah)}

Hiwar qishashi yaitu sebuah kisah yang keseluruhannya merupakan dialog langsung, yaitu pada masa sekarang, namun hiwar dalam al-Qur'an tidak dimaksudkan bersandirwara. Cirri khas dari hiwar qishahsi ini adalah penonjolan dialog dalam sebuah kisah, seperti kisan Nabi Syu'aib dalam surat Hud ayat 88.

Rasulullah Saw. pernah bercerita mengenai kehidupan orang-orang Bani Israil yang selau didampingi para Nabi, sampai Nabi tersebut meninggal dan digantikan oleh Nabi yang lain.

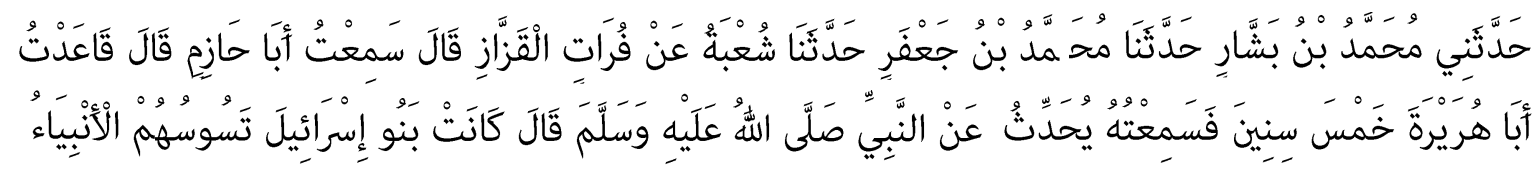




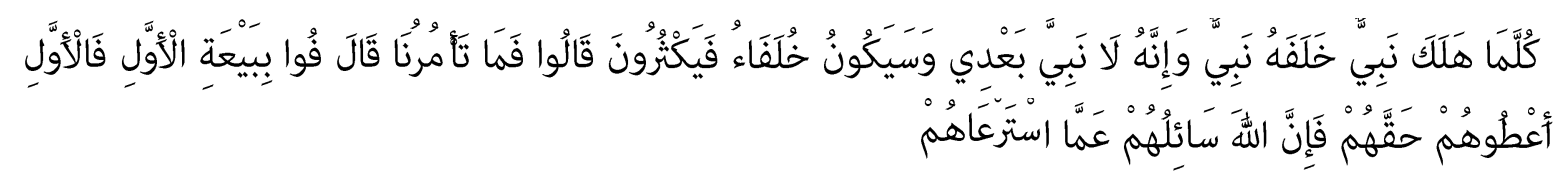

Telah bercerita kepadaku Muhammad bin Basysyar telah bercerita kepada kami Muhammad bin Ja'far telah bercerita kepada kami Syu'bah dari Furat Al Qazaz berkata, aku mendengar Abu Hazim berkata; "Aku bidup mendampingi Abu Hurairah radliallabu 'anbu selama lima tabun dan aku mendengar dia bercerita dari Nabi shallallabu 'alaibi wasallam yang besabda: "Bani Isra'il, kehidupan mereka selalu didampingi oleh para Nabi, bila satu Nabi meninggal dunia, akan dibangkitkan Nabi setelabnya. Dan sungguh tidak ada Nabi sepeninggal aku. Yang ada adalab para khalifah yang banyak jumlahnya". Para shahabat bertanya; "Apa yang baginda perintabkan kepada kami?". Beliau menjawab: "Penuibilah bai' at kepada khalifah yang pertama (lebih dabulu diangkat), berikanlah hak mereka karena Allah akan bertanya kepada mereka tentang pemerintahan mereka". (HR. Bukhari: 3196)

\section{Hiwar jadali (percakapan untuk menetapkan hujjah)}

Hiwar dalam bentuk ini adalah hiwar yang melahirkan bentuk diskusi atau perdebatan yang bertujuan untuk menetapkan bujjah kepada peserta diskusi. Hiwar jadali ini misalnya digambarkan dalam al-Qur'an An-Najm ayat 1-5 yang menjelaskan tentang kebenaran sabda Rasulullah Saw. mengenai peristiwa Isra' Mi'raj.

Selain itu, dalam sebuah hadits Nabi Saw. pernah menetapkan hukuman qishash kepada Ruba saudara Anas bin An Nadhr yang telah memcahkan gigi wanita lain.

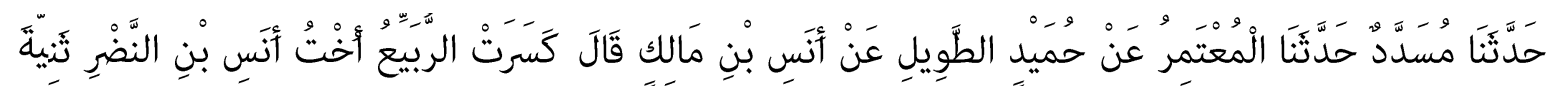

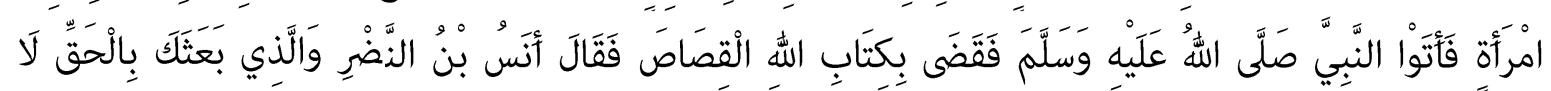

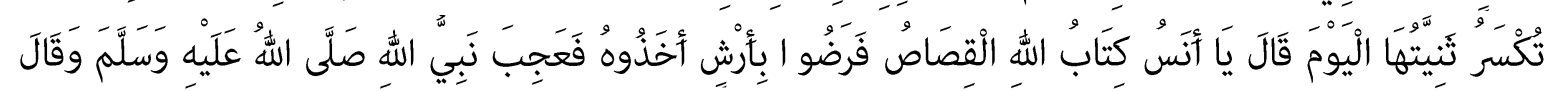

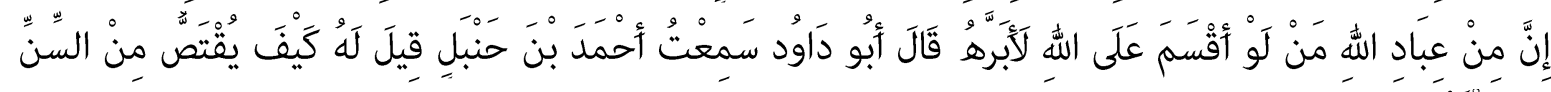
قَالَ تُبْرد

Telah menceritakan kepada kami Musaddad berkata, telah menceritakan kepada kami Al Mu'tamir dari Humaid Ath Thawil dari Anas bin Malik ia berkata, "Ruba' -saudara wanita Anas bin An Nadhr-memecabkan gigi seorang wanita, mereka lalu mendatangi Nabi shallallabu 'alaibi wasallam, lantas beliau memutuskan dengan kitab Allah, yakni qishas. Anas bin An Nadhr berkata, "Demi Drat yang mengutusmu dengan kebenaran, hari ini giginya tidak. akan dipecah (qishas)!" beliau bersabda: "Wahai Anas, ketentuan Kitabullah adalah qishas!" Kemudian mereka pun rela dengan mengambil diyatnya. Dengan ta'ajub Nabi shallallabu 'alaibi wasallam bersabda: "Sungguh, di antara bamba Allah ada seseorang yang jika ia bersumpah pasti akan dikabulkan." Abu Dawnd berkata, "Aku mendengar Ahmad bin Hanbal ditanya, "Bagaimana mengqishas gigi?" Ia menjawab, "Dirampalkan." (HR. Abu Daud: 3979)

Didalam hadits yang lain ketika yang diriwayatkan oleh An-Nasa'i yakni ketika Rasulullah untuk memotong tangan seorang pencuri, setelah sebelumnya adanya dialog antara Nabi Saw. dan para sahabat.

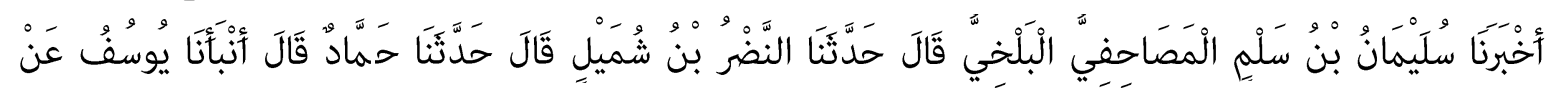

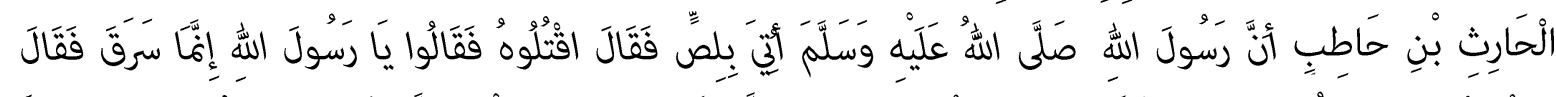

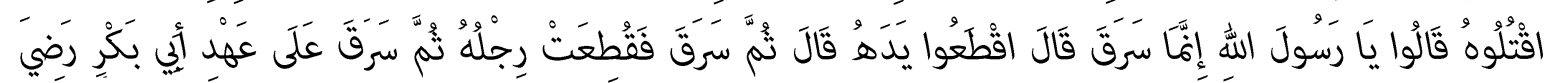

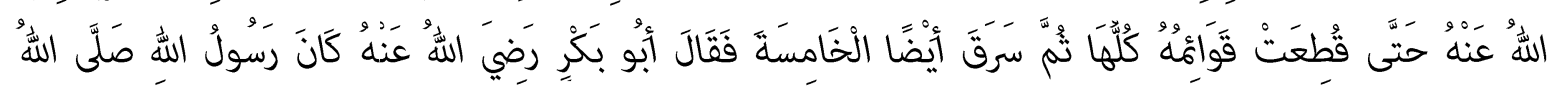




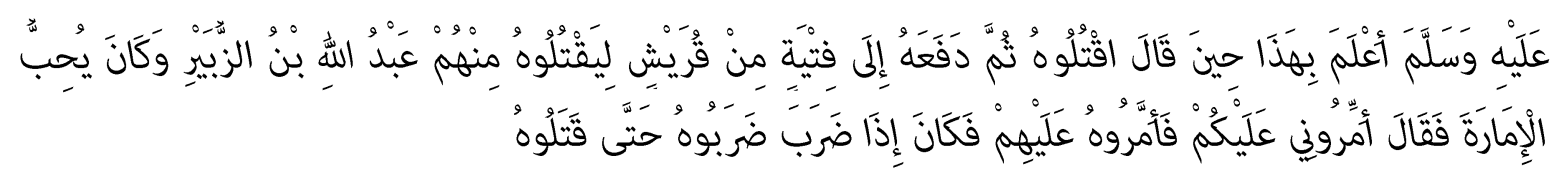

Telah mengkhabarkan kepada kami Sulaiman bin Salm Al Mashahifi Al Balkhi, dia berkata; telah menceritakan kepada kami An Nadbr bin Syumail, dia berkata; telah menceritakan kepada kami Hammad, dia berkata; telah memberitakan kepada kami Yusuf dari Harits bin Hathib babwa dibadapkan seorang pencuri kepada Rasulullab shallallabu 'alaibi wasallam, lalu beliau bersabda: "Bunublab dia, " Para sababat berkata; "Wabai Rasulullah, dia hanya mencuri." Beliau bersabda: "Bunublah dia, " Para sababat berkata; "Wahai Rasulullab; dia hanya mencuri." Beliau bersabda: "Potonglah tangannya." Harits bin Hathib berkata; Kemudian dia mencuri lagi maka dipotonglah kakinya. Lalu pada masa Abu Bakar radliallahu 'anbu dia mencuri lagi bingga dipotonglah semua pergelangannya. Tapi dia masih mencuri lagi hingga yang kelima kalinya, maka berkatalah Abu Bakar radliallahu 'anhu; "Rasulullah shallallahu 'alaibi wasallam lebih mengetabui mengenai hal ini ketika beliau bersabda; "Bunublah dia". Lalu dia menyerahkannya kepada beberapa orang pemuda Quraisy agar mereka membunubnya. Di antara mereka adalah Abdullah bin $A z$ Zubair, dia adalah seorang yang senang menjadi pemimpin. Dia berkata; "Angkatlah aku sebagai pemimpin kalian!" Lalu mereka mengangkatnya sebagai pemimpin, jika dia memukul maka mereka (pun ikut) memukulnya bingga mereka membunubnya (pencuri tersebut)." (HR. Nasa'i: 4891)

\section{Hiwar Nabawi}

Rasulullah Saw. selalu mengambil pelajaran dari setiap macam dan bentuk hiwar serta metode pendidkan yang telah ditetapkan dalam al-Qur'an. Akhlak beliau adalah al-Qur;an dan kehidupan, pendidikan serta pengajaran meruppakan pengamalan dari ayat-ayat dan wahyu Allah Swt serta kandungan makna yang tersirat didalamnya.

Hiwar merupakan metode Nabi Saw. dalam mengajar para sahabatnya baik langsung maupun tidak langsung. Bahkan, beliau mengharapkan para sahabat untuk bertanya, sampai pada akhirnya malaikat Jibril turun dan berada ditengah-tengah antara para sahabat dan memulai bertanya, karena sebelumnya para sahabat belum ada yang berani untuk bertanya.

\section{SIMPULAN}

Berdasarkan pembahasan di atas maka dapat disimpulkan bahwa materi pendidikan yang terdapat dalam hadits Jibril, antara lain, pertama, materi keimanan (akidah). Materi keimanan (akidah) menempati posisi sentral karena materi ini adalah pondasi untuk menetukan masa depan seorang peserta didik menjadi manusia yang baik atau sebaliknya. Kedua, materi fiqh (syariat), adalah materi yang berisikan mengenai hukum-hukum, tata cara berkehidupan yang kesemuanya diatur di dalamnya, misalnya tata cara bermualah atau bersosialisasi terhadap orang lain, berjual beli dan lain sebagainya. Ketiga, akblak. Tujuan akhir sebuah pendidikan adalah selain menjadikan peserta didikan seseorang yang berpengetahuan adalah memiliki akhlak yang baik. Maka, dalam hal ini penulis beranggapan bahwa materi akhlak juga harus memberikan penekanan yang tinggi kepada peseta didik.

Kemudian metode pembelajaran dalam prespektif hadits Jibril, penulis memberikan penekanan bahwa metode yang digunakan Nabi SAW dalam menyampaikan materi dalam hadits Jibri adalah metode hiwar (dialog, tanya-jawab). Metode Hiwar sendiri terdapat beberapa macam, yaitu: biwar khithabi atau ta'abudi (percakapan pengabdian), hiwar washfi 
(percakapan deskriptif), biwar qishashi (percakapan berkisah), biwar jadali (percakapan untuk menetapkan bujjab), dan biwar nabawi.

\section{DAFTAR PUSTAKA}

Alfiah. 2010. Hadits Tarbawiy (Pendidikan Islam dan Tujuan Hadits). Pekanbaru: Al-Mujtahadah Press.

Arifin. 1996. Ilmu Pendidikan Islam. Jakarta: Bumi Aksara.

Gulo. 2002. Strategi Belajar Mengajar. Jakarta: Grasindo.

Imran, Ali. 2012. "Kosep Adil dan Ihsan Menurut Aqidah, Ibadah dan Akhlak”, dalam Jurnal Hikmah 6 (2): Juli.

Indrawan, Irjus. 2013. "Model Pembelajaran Nabi Muhammad Saw. (Hiwar, Analogi, Tasbih dan Amtsal)", dalam Jurnal Al-Afkear 2 (2): Oktober.

Izzan, Ahmad dan Saehuddin. 2016. Hadits Pendidikan. Bandung: Humaniora.

Kaelany HD. 2000. Iman, Imu dan Amal Saleh. Jakarta: Rineka Cipta.

Poerdarwinta, WJS. 2000. Kamus Bahasa Indonesia. Jakarta: Balai Pustaka.

Khon, Abdul Majid. 2004. Hadits Tarbawi "Hadits-hadits Pendidikan". Jakarta: Kencana Prenadamedia Grup.

Ibnu Majah. t.th. Sunan Ibnu Majah Juz I Bab Muqadimah. Semarang: Thaha Putra.

Umar, Bukhari. 2016. Hadits Tarbawi (Pendidikan Dalam Prespektif Hadits). Jakarta: Amzah. 